ORIGINAL ARTICLE / ARTIGO ORIGINAL

\title{
Factors associated with risk of malnutrition in the elderly in south-eastern Brazil
}

\section{Fatores associados a risco de desnutrição em idosos do sudeste do Brasil}

\author{
Renata Damião', Álvaro da Silva Santos", Alicia Matijasevich"', Paulo Rossi Menezes 'II
}

\begin{abstract}
Objective: The aim of this study was to evaluate the prevalence of malnutrition risk and its association with socioeconomic, behavioral, and health characteristics in the community-dwelling elderly. Methods: A cross-sectional study with individuals aged $\geq 60$ years. Nutritional status was evaluated using the Mini Nutritional Assessment. Socioeconomic, behavioral, and health information was also collected from all participants. The association between each variable and the risk of malnutrition was calculated and adjusted using Poisson hierarchical regression. Results: The initial sample consisted of 3,101 elderly people, of whom $28.3 \%(95 \% \mathrm{CI} 25.3-31.4 \%)$ were at risk of malnutrition. The multivariate analysis showed that the risk of malnutrition was significantly higher in women without formal education, who did not live with a partner, and identified as black-skinned. The risk of malnutrition was twice as high in individuals with no family income as compared to those who earned at least three minimum wages. Smokers were also more likely to be at risk of malnutrition than individuals who had never smoked. Participants suffering from kidney, respiratory or heart disease were at higher risk of malnutrition than those with no history of such illnesses. Conclusion: These findings could be used to help in the development of health policies and in the establishment of adequate programs aimed at reducing the risk of malnutrition in this population.
\end{abstract}

Keywords: Nutrition. Nutritional Status. Elderly. Mini Nutritional Assessment.

'Department of Nutrition, Postgraduate Program in Physical Education, Universidade Federal de Minas Gerais - Uberaba (MG), Brazil. "Department of Nursing, Postgraduate Program in Healthcare, Universidade Federal de Minas Gerais - Uberaba (MG), Brazil. "'Department of Preventive Medicine, Universidade de São Paulo - São Paulo (SP), Brazil.

Corresponding author: Renata Damião. Postgraduate Program in Physical Education, Federal University of Triângulo Mineiro. Avenida Tutunas, 490, CEP: 38061-500, Uberaba, MG, Brazil. E-mail: damiaorenata@hotmail.com

Conflict of interests: nothing to declare - Financial support: funded by the Research Support Foundation of Minas Gerais (FAPEMIG), grant number APQ-00995-11. 
RESUMO: Objetivo: O objetivo do trabalho foi avaliar a prevalência do risco de desnutrição e sua associação com fatores socioeconômicos, hábitos comportamentais e condições de saúde em idosos residentes na comunidade. Metodologia: Estudo transversal, realizado com indivíduos com $\geq 60$ anos de idade. O estado nutricional foi avaliado pela Mini Avaliação Nutricionale foram obtidas informações socioeconômicas, hábitos comportamentais e de condições de saúde. Para a identificação dos fatores associados ao risco de desnutrição foram realizadas análises brutas e ajustadas por meio da regressão de Poisson, utilizando modelo hierárquico. Resultados: Foram analisados 3.101 idosos e, destes, 28,3\% (IC95\% 25,3 - 31,4) foram classificados com risco de desnutrição. Na análise multivariada, a prevalência de risco de desnutrição foi significantemente maior entre as mulheres, sem escolaridade, que não vivem com parceiros e cor de pela preta. O risco de desnutrição foi duas vezes maior nos indivíduos sem renda quando comparados aos que recebem acima de três salários mínimos. Os fumantes demonstraram maior probabilidade de risco de desnutrição quando comparados com os não fumantes. Os indivíduos que autorrelataram ter doenças renais, respiratórias e cardíacas apresentaram maior risco de desnutrição que aqueles que não relataram esses problemas. Conclusão: Estes resultados podem servir de subsídio para a formação de políticas de saúde no estabelecimento de programas adequados visando a redução do risco de desnutrição nesta população.

Palavras-chave: Nutrição. Estado Nutricional. Idosos. Avaliação Nutricional.

\section{INTRODUCTION}

The risk of malnutrition, or of being in the pre-malnutrition stage, is an important public health concern in elderly populations. A study pointed a prevalence of $31.9 \%$ of community-dwelling elderly individuals, and $46.2 \%$ of frail elderly persons living in the community, hospitals or institutions were found to be at risk of malnutrition ${ }^{1}$. These findings suggest that the early treatment of those at risk of malnutrition may reduce the prevalence of this condition in elderly populations ${ }^{2}$.

Nutritional impairment has a clear negative impact on the individual, as well as on his/ her family and country. Malnutrition is an independent risk factor for mortality ${ }^{3}$. The mortality rate in malnourished elderly Brazilians aged between 60 and 69 years was 3.34 deaths per 1,000 inhabitants, and among those aging 70 years or more, 11 deaths per 1,000 inhabitants ${ }^{4}$. In addition, heart disease ${ }^{5}$, respiratory disease ${ }^{6}$, and frailty are strongly associated with malnutrition $^{7}$. Several social and behavioral factors were also found to be associated with malnourishment ${ }^{8,9}$. However, the risk of malnutrition has not been sufficiently explored in the literature.

Added to this, an ageing population is no longer a feature specific to developed countries ${ }^{10}$. In 2010, according to the Brazilian Institute for Geography and Statistics (IBGE), 20,590,599 Brazilian citizens were aged 60 years or older, which amounts to $10.8 \%$ of the national population $^{11}$. Average life expectancy has also increased in recent decades, reaching 74 years in 2012 and remaining higher for women than for men ( 78 and 71 years, respectively $)^{12}$. This has fostered the discussion about the concept of quality-adjusted or 'healthy' life expectancy, which examines the maintenance of functioning and quality of life in old age ${ }^{13}$. 
Nutritional status and nutritional risk directly impacts quality of life. According to Ferreira et al. $^{14}$, the risk of malnutrition is an important contributor to mortality in elderly populations.

The risk of malnutrition and any associated factors must therefore be studied to minimize their economic and social costs. The identification of factors associated may help in the implementation of nutritional intervention programs against malnutrition in the elderly. The aim of this study was to evaluate the prevalence of malnutrition risk and its association with socioeconomic, behavioral, and health features in community-dwelling elderly people from Triângulo Mineiro region, Minas Gerais State.

\section{METHODS}

\section{STUDY DESIGN AND POPULATION}

This was a cross-sectional study with a target population of 80,134 individuals aged 60 years or older ${ }^{11}$, conducted as part of a project entitled 'Health profile of the elderly population of the health region of Uberaba/Minas Gerais', which aimed to investigate the sociodemographic and health profile of the elderly population of 27 cities located in Triângulo Mineiro region, Minas Gerais State, south-eastern Brazil.

Sample size was calculated based on the elderly population of each city ${ }^{11}$ and according to the following parameters: $5 \%$ sampling error, $95 \%$ confidence interval, and proportion of elderly individuals per city (the elderly divided by total population). The minimum sample size, calculated as the sum of minimum sample sizes, was 3,513.

As per the municipal Health Department and Family Health, all individuals aged 60 or older living in the urban regions were invited to go to the Primary Health Care Units of their municipalities to participate in the assessment.

The following inclusion criterion was applied to all participants: scores above the minimum threshold on the Mini Mental State Examination ${ }^{15}$. The score of the MMSE was adjusted by education according to Bertolucci et $\mathrm{al}^{16}$. Exclusion criteria were: wheelchair bound, having severe hearing or visual impairments which interfered with communication, and being bedridden.

All research protocols were approved by the Human Research Ethics Committee of Universidade Federal de Minas Gerais (protocol number 1640/2010), and by the Research Ethics Committee of the Medical School of Universidade de São Paulo (protocol number 083/15).

\section{DATA COLLECTION}

Data were collected between May 2012 and April 2013. A multidimensional questionnaire was applied individually to each participant by a trained interviewer after they signed the informed consent form. A pilot study was performed in three cities of the health region of Uberaba in order to test questionnaire viability, which resulted in minor changes to the instrument in question. 
Nutritional status was evaluated using the Mini Nutritional Assessment (MNA) translated into Portuguese ${ }^{17}$. Total score $\geq 24$ indicates satisfactory nutritional status, scores between 17 and 23.5 indicate risk of malnutrition, and $<17$ means actual malnutrition. The MNA is a valid, highly sensitive (96\%) and specific (98\%) instrument for the assessment of nutritional status in the elderly ${ }^{18,19}$.

\section{ANTHROPOMETRIC ASSESSMENT}

Anthropometric measures were taken using the standard techniques proposed by Lohman et $\mathrm{al}^{20}$. All assessments were performed by trained professionals with the same supervisor (a nutritionist). Body mass was measured to the nearest $50 \mathrm{~g}$ using a Filizola ${ }^{\circledR}$ portable electronic scale, with maximum capacity of $150 \mathrm{~kg}$. Height $(\mathrm{m})$ was measured using a portable stadiometer. Body mass index was determined using the following formula: BMI = body mass $/$ height $^{2}$. Mid-arm and calf circumferences were measured to the nearest $\mathrm{mm}$ using an inelastic flexible measuring tape.

\section{SOCIOECONOMIC, BEHAVIORAL, AND HEALTH CHARACTERISTICS}

Three sets of independent variables were considered:

1. Gender (female and male), age range (60 - 69, $70-79$ and $\geq 80$ years), education (none, 1 to 4 years, $\geq 5$ years), living arrangement (alone or accompanied), skin color (white, yellow, brown, black), family income $(0, \sim 1$ minimum wage, $>1$ and $\leq 3$ minimum wages, $>3$ minimum wages);

2. Smoking history (never, former smoker, current smoker), current alcohol consumption (yes, no);

3. Evaluated by self-report, using the following question: "Has a doctor ever told you that you have or had any of the following diseases: diabetes, hypertension, cancer, respiratory, rheumatic, musculoskeletal, heart or kidney disease?".

\section{DATA ANALYSIS}

Data were input in duplicate into a Microsoft Office 2007 Excel $^{\circledR}$ spreadsheet. Statistical analyses were performed using Stata ${ }^{\circledR}$ version 11.0.

Malnourished individuals were excluded from the analysis. Descriptive analyses were first performed, with all results presented as percentages. The association between each risk factor and the risk of malnutrition was calculated and adjusted using the Poisson regression test. Results were considered significant when $\mathrm{p}<0.05$.

Since several factors could confound the association between variables of interest, hierarchical analysis was used to select the most important confounders. The hierarchical approach 
accounts for the effects of each confounder on the same and superior levels ${ }^{21}$. Multivariate analysis using a hierarchical model (Figure 1) was used to evaluate all independent variables associated with the risk of malnutrition. Socioeconomic factors were not adjusted for the effects of any other variables, since the theoretical model selected considers them to be determined by social features. As a result, behavioral factors were adjusted for socioeconomic variables, and health-related factors were adjusted for both socioeconomic and behavioral ones. Variables with $\mathrm{p} \leq 0.20$ within each level were considered potential confounders ${ }^{22}$.

\section{RESULTS}

Of the 3,430 elderly individuals who took part in the study, $329(9.6 \%)$ did not have all the desired sociodemographic information. However, 54 of these individuals $(1.7 \%)$ were classified as malnourished. The final sample, therefore, consisted of 3,047 individuals, of whom 865 (28.3\%) were at risk of malnutrition.

In the crude analysis, all variables were significantly associated with a risk of malnutrition in the sample, exceptions being hypertension and diabetes. After adjustments based on our hierarchical model, only the following variables remained as associated with risk of malnutrition: gender, education, skin color, income, not living with a partner, smoking habit, respiratory, heart and kidney disease (Table 1).

According to the multivariate analysis (Table 1), the risk of malnutrition was significantly higher in females (PR $=1.19,95 \% \mathrm{CI} 1.05-1.34)$, individuals with no formal education $(\mathrm{PR}=1.63,95 \% \mathrm{CI} 1.32-2.00)$ and subjects not living with a partner $(\mathrm{PR}=1.17,95 \% \mathrm{CI}$ $1.04-1.32)$. Individuals identified as black-skinned were 1.21 times $(1.04-1.41)$ more likely to be at risk of malnutrition than those identified as white-skinned. The risk of malnutrition was twice as high in individuals with no family income compared to those who earned at least three times a minimum wage $(\mathrm{PR}=2.21,95 \% \mathrm{CI} 1.42-3.70)$. Smokers were also more likely to be at risk of malnutrition $(\mathrm{PR}=1.63,95 \% \mathrm{CI} 1.42-1.86)$ than individuals who had

Block 1: Socioeconomic Variables

(gender, age range, education, skin color, income, living arrangement)

Block 2: Behavioral Variables

(smoking habit, alcohol intake)

Block 3: Health Conditions

(diabetes, hypertension, cancer, respiratory disease, rheumatic disease, musculoskeletal disease, heart or kidney disease)

Malnutrition risk

Figure 1. Hierarchical theoretical model for malnutrition risk in elderly individuals. 
Table 1. General characteristics, prevalence of malnutrition risk, raw prevalence ratios and adjusted values for socioeconomic, behavioral and health variables, Uberaba, 2013.

\begin{tabular}{|c|c|c|c|c|c|c|}
\hline \multirow{2}{*}{ Variables } & Frequency & $\begin{array}{l}\text { Malnutrition } \\
\text { risk }\end{array}$ & Crude & \multirow{2}{*}{$\begin{array}{c}\text { p- } \\
\text { value* }\end{array}$} & Adjusted & \multirow{2}{*}{$\begin{array}{c}\text { p- } \\
\text { value }\end{array}$} \\
\hline & n (\%) & n (\%) & PR (95\% Cl) & & $\mathrm{P}(95 \% \mathrm{Cl})$ & \\
\hline
\end{tabular}

Block 1

\begin{tabular}{|c|c|c|c|c|c|c|}
\hline Gender & & & & & & \\
\hline Male & $1,180(38.7)$ & 292 (24.7) & 1 & \multirow{2}{*}{0.001} & 1 & \multirow{2}{*}{0.006} \\
\hline Female & $1,867(61.2)$ & $570(30.5)$ & $1.23(1.09-1.39)$ & & $1.19(1.05-1.34)$ & \\
\hline \multicolumn{7}{|l|}{ Age Range } \\
\hline $\begin{array}{l}60 \text { to } 69 \\
\text { years }\end{array}$ & $1,611(52.8)$ & $417(25.8)$ & 1 & \multirow{3}{*}{0.000} & 1 & \multirow{3}{*}{0.160} \\
\hline $\begin{array}{l}70 \text { to } 79 \\
\text { years }\end{array}$ & $1,083(35.5)$ & $321(29.6)$ & $1.14(1.01-1.29)$ & & $1.05(0.93-1.19)$ & \\
\hline$\geq 80$ years & $353(11.5)$ & $124(35.1)$ & $1.35(1.15-1.59)$ & & $1.17(0.99-1.39)$ & \\
\hline \multicolumn{7}{|l|}{ Education } \\
\hline None & 895 (29.3) & 347 (38.7) & $1.98(1.62-2.42)$ & & $1.63(1.32-2.00)$ & \multirow{3}{*}{0.000} \\
\hline 1 to 4 years & $1,670(54.8)$ & $421(25.2)$ & $1.29(1.05-1.57)$ & & $1.14(0.93-1.39)$ & \\
\hline $\begin{array}{l}5 \text { or more } \\
\text { years }\end{array}$ & $482(15.8)$ & $94(19.5)$ & 1 & & 1 & \\
\hline \multicolumn{7}{|l|}{ Skin colour } \\
\hline White & $1,831(60.0)$ & $479(26.1)$ & 1 & \multirow{4}{*}{0.001} & 1 & \multirow{4}{*}{0.040} \\
\hline Yellow & $64(2.1)$ & $23(35.9)$ & $1.37(0.98-1.92)$ & & $1.25(0.90-1.75)$ & \\
\hline Brown & $738(24.2)$ & $219(29.6)$ & $1.13(0.99-1.29)$ & & $1.12(0.98-1.28)$ & \\
\hline Black & $414(13.5)$ & $141(34.0)$ & $1.30(1.11-1.51)$ & & $1.21(1.04-1.41)$ & \\
\hline
\end{tabular}

Family income (in minimum wages)†

\begin{tabular}{|c|c|c|c|c|c|c|}
\hline 0 & $42(1.3)$ & $16(38.1)$ & $2.77(1.75-4.41)$ & \multirow{4}{*}{0.000} & $2.29(1.42-3.70)$ & \multirow{4}{*}{0.000} \\
\hline 1 & $1,138(37.3)$ & $386(33.9)$ & $2.47(1.89-3.23)$ & & $1.96(1.49-2.58)$ & \\
\hline$>1 \leq 3$ & $1,495(49.0)$ & $409(27.3)$ & $1.99(1.52-2.60)$ & & $1.76(1.34-2.31)$ & \\
\hline$>3$ & $372(12.2)$ & $51(13.7)$ & 1 & & 1 & \\
\hline
\end{tabular}

Living arrangement

\begin{tabular}{l|c|c|c|c|c|c|}
\hline Accompanied & $1,747(57.3)$ & $431(24.6)$ & 1 & 1 & 0.006 \\
\hline Alone & $1,300(42.6)$ & $431(33.1)$ & $1.34(1.20-1.50)$ & & $1.17(1.04-1.32)$ & \\
\end{tabular}


Table 1. Continuation.

\begin{tabular}{|c|c|c|c|c|c|c|}
\multirow{2}{*}{ Variables } & Frequency & $\begin{array}{c}\text { Malnutrition } \\
\text { risk }\end{array}$ & Crude & $\begin{array}{c}p- \\
\text { value* }\end{array}$ & Adjusted & $\begin{array}{c}p- \\
\text { value* }^{*}\end{array}$ \\
\cline { 2 - 4 } & $\mathrm{n}(\%)$ & $\mathrm{n}(\%)$ & $\mathrm{PR}(95 \% \mathrm{Cl})$ & $\mathrm{P}(95 \% \mathrm{Cl})$ &
\end{tabular}

Block 2

\begin{tabular}{|c|c|c|c|c|c|c|}
\hline Smoking s & & & & & & \\
\hline Never & $1,816(59.6)$ & $473(26.0)$ & 1 & \multirow{3}{*}{0.000} & 1 & \multirow{3}{*}{0.000} \\
\hline $\begin{array}{l}\text { Former } \\
\text { smoker }\end{array}$ & $785(25.8)$ & $205(26.1)$ & $1.00(0.87-1.15)$ & & $1.10(0.95-1.27)$ & \\
\hline $\begin{array}{l}\text { Current } \\
\text { smoker }\end{array}$ & $446(14.6)$ & $184(41.2)$ & $1.58(1.38-1.81)$ & & $1.63(1.42-1.86)$ & \\
\hline \multicolumn{7}{|c|}{ Alcohol intake } \\
\hline No & $2,562(84.0)$ & $753(29.3)$ & 1 & \multirow{2}{*}{0.003} & 1 & \multirow{2}{*}{0.080} \\
\hline Yes & 485 (15.9) & $109(22.4)$ & $0.76(0.64-0.91)$ & & $0.85(0.71-1.01)$ & \\
\hline
\end{tabular}

Block 3

\begin{tabular}{|c|c|c|c|c|c|c|}
\hline No & 1,007 (33.3) & 277 (32.5) & 1 & \multirow{2}{*}{0.566} & \multirow{2}{*}{-} & \\
\hline Yes & $2,010(66.7)$ & $573(67.5)$ & $1.03(0.91-1.17)$ & & & \\
\hline \multicolumn{7}{|c|}{ Diabetes } \\
\hline No & $2,374(79.8)$ & $656(78.3)$ & 1 & \multirow{2}{*}{0.201} & & \multirow[b]{2}{*}{-} \\
\hline Yes & $602(20.2)$ & $182(21.7)$ & $1.09(0.95-1.25)$ & & & \\
\hline \multicolumn{7}{|c|}{ Cancer } \\
\hline No & $2,861(96.1)$ & 795 (27.7) & 1 & \multirow{2}{*}{0.119} & 1 & \multirow{2}{*}{0.248} \\
\hline Yes & $114(3.8)$ & $39(34.2)$ & $1.23(0.94-1.59)$ & & $1.17(0.89-1.52)$ & \\
\hline \multicolumn{7}{|c|}{ Respiratory disease } \\
\hline No & $2,538(84.8)$ & $674(26.5)$ & 1 & \multirow{2}{*}{0.000} & 1 & \multirow{2}{*}{0.004} \\
\hline Yes & $455(15.2)$ & $171(37.5)$ & $1.41(1.23-1.61)$ & & $1.24(1.07-1.44)$ & \\
\hline \multicolumn{7}{|c|}{ Rheumatic disease } \\
\hline No & $1,985(68.4)$ & $522(26.3)$ & 1 & \multirow{2}{*}{0.002} & 1 & \multirow{2}{*}{0.396} \\
\hline Yes & $914(31.5)$ & $291(31.8)$ & $1.21(1.07-1.36)$ & & $1.06(0.92-1.21)$ & \\
\hline \multicolumn{7}{|c|}{ Musculoskeletal disease } \\
\hline No & $1,789(62.3)$ & $477(26.6)$ & 1 & \multirow{2}{*}{0.025} & 1 & \multirow{2}{*}{0.385} \\
\hline Yes & $1,081(37.6)$ & $330(30.5)$ & $1.14(1.01-1.28)$ & & $1.0(0.92-1.21)$ & \\
\hline \multicolumn{7}{|c|}{ Heart disease } \\
\hline No & $2,164(74.3)$ & $526(24.3)$ & 1 & \multirow{2}{*}{0.000} & 1 & \multirow{2}{*}{0.000} \\
\hline Yes & $747(25.6)$ & $286(38.2)$ & $1.57(1.40-1.77)$ & & $1.42(1.25-1.61)$ & \\
\hline \multicolumn{7}{|c|}{ Kidney disease } \\
\hline No & $2,532(86.0)$ & $665(26.2)$ & 1 & \multirow{2}{*}{0.000} & 1 & \multirow{2}{*}{0.002} \\
\hline Yes & $410(13.9)$ & $155(37.8)$ & $1.43(1.25-1.65)$ & & $1.27(1.09-1.48)$ & \\
\hline
\end{tabular}

*Wald's Test; ${ }^{~}$ Minimum wage at the time of the study $=R \$ 678$. 
never smoked. Participants suffering from kidney, respiratory and heart diseases were at higher risk of malnutrition than those with no history of such illnesses $[(\mathrm{PR}=1.27,95 \% \mathrm{CI}$ 1.09 - 1.48); $(\mathrm{PR}=1.24,95 \% \mathrm{CI} 1.07-1.44) ;(\mathrm{PR}=1.42$, 95\%CI 1.25 - 1.61); respectively]. Age, alcohol intake, cancer, rheumatic and musculoskeletal diseases were not associated with risk of malnutrition.

\section{DISCUSSION}

The present findings revealed that female elderly individuals who had no formal education, identified as black-skinned, with lower income levels, not living with a partner, smoker or with respiratory, heart or kidney diseases were more likely to be at risk of malnutrition.

There is no shortage of population-based studies conducted with Brazilian elderly people residing in the community in which the risk of malnutrition was assessed by MAN.

The Health, Well-being and Ageing (SABE) study, for instance, was a multicenter research project performed by the Pan-American Health Organization in several Latin American cities, including São Paulo. In this investigation, $25.6 \%$ of a retrospective sample of 1,170 elderly individuals were found to be at risk of malnutrition ${ }^{14}$.

Our findings were also similar to those obtained in other countries in investigations such as the Aging and Malnutrition in Elderly Lebanese (AMEL) study, by Boulos et al. ${ }^{23}$. The risk of malnutrition was seen in $29.1 \%$ of the sample and was especially frequent in women. On the other hand, in a prospective cohort study conducted in the Razavi Khorasan province of Iran involving 2,000 elderly ( $\geq 60$ years) people living in both rural and urban areas, the prevalence of malnutrition risk was $45.3 \%{ }^{8}$.

The variation in prevalence of malnutrition risk between studies who used the same assessment method can be explained by differences in the age used to define 'elderly' (which is 60 years in Brazil) $)^{24}$, or by the inclusion of individuals living in urban vs. rural areas, subjects with cognitive impairment, and frail elderly persons.

A significant number of studies have identified a negative correlation between socioeconomic status and malnutrition risk in elderly individuals ${ }^{8,9,25}$. In the present study, income (mostly derived from social security) was the socioeconomic variable with the strongest association with malnutrition risk, even after adjustment to potential confounding factors. This association was strongest in lower income brackets. Brazil is a country with many notable cultural, social and economic contrasts, which may influence dietary habits and the risk of malnutrition in the elderly, especially those with lower incomes. A progress in human development was observed in all regions of Minas Gerais, but regional inequality persists ${ }^{26}$.

Lower income may restrict access to healthy food and limit dietary options, leading to dietary monotony and inability to maintain adequate nutrition ${ }^{9}$. Additionally, many elderly people provide financial assistance to their children and relatives ${ }^{10}$, which may aggravate this situation. 
The present study found an especially high prevalence of malnutrition risk among women, which corroborates with previous findings ${ }^{27}$. Female life expectancy exceeds male life expectancy across the world ${ }^{28}$. Thus, aging may expose the elderly to diseases and their complications, predisposing them to the risk of malnutrition ${ }^{7}$. Other possible factors are social issues related to social and financial living.

In many societies, women are more likely to have low income and poor social support, both of which can persist and worsen in old age. With the objective of determining the prevalence of food insecurity in Brazilian households whose heads are elderly people, according to sociodemographic characteristics, Rosa et al. ${ }^{29}$ found that $29.8 \%$ were food-insecure. In gender analysis, women-headed households found themselves in a worse food security situation compared to those headed by men.

Education was also strongly associated with malnutrition risk in the present study, with elderly individuals who had never attended school showing a significantly higher risk of malnutrition. A relationship between low education levels and risk of malnutrition was also demonstrated by Timpini et al. ${ }^{30}$ and another study in which elderly individuals with higher education levels were found to have better nutritional status ${ }^{8}$.

Moreira et al. ${ }^{31}$ found that individuals with higher education levels eat more vegetables, fruit, milk, and fish as compared to those with lower education levels. The authors suggested that a higher education level may be associated with increased access to information and better understanding of the importance of certain foods for nutrition and health, all of which positively impacting nutritional status. Additionally, individuals with higher education levels may have a higher income and, consequently, increased access to more expensive and high-quality food items.

The increased prevalence of malnutrition risk in individuals who identify as having black skin color may be explained by inequality and increased exposure to adverse social conditions. There is a significant racial diversity in Brazil and the percentage of the population with black skin color is $11.7 \%$ for men and $12.0 \%$ for women over $60^{32}$. The same study showed that the population of Brazil with black skin is especially susceptible to social inequality and adverse living conditions, in addition to having lower education and income levels. These issues are especially common among women. In a survey of a representative probabilistic sample of 18,684 elderly people from all regions of Brazil, which aimed to analyze the association between skin color/race and health indicators, racial inequality was found to have a significant impact on health, as well as socioeconomic and demographic conditions. Elderly people with brown and black skin color are more numerous in the younger age brackets ( $65-69$ years), in populations which rely exclusively on public health, among those with lower education levels, in the lowest income quintile, and in areas with poorer social and health conditions $\mathrm{s}^{33}$.

In the present study, the increased risk of malnutrition in elderly individuals who live alone may represent the influence of social interaction (or lack thereof) on nutritional status. Locher et al. ${ }^{34}$ found that, although the presence of family members in the household had no effect on calorie intake, elderly individuals who ate with someone else consumed 
an average of more $114.0 \mathrm{kcal}$ per meal than those who ate alone. The authors suggested that this phenomenon may be explained by the increased duration of meals when others are present, which may increase food intake. Romero-Ortuno et al. ${ }^{35}$ also observed that the lack of social support was a more significant risk factor for malnutrition than living alone.

The association between smoking and malnutrition risk has also been observed in other studies $^{36,37}$. This may be explained by the fact that nicotine raises the resting metabolic rate without the expected increase in appetite, as well as lipolysis, facilitating weight loss ${ }^{38}$. Additionally, smoking is associated with several health issues, which may increase mortality in underweight elderly people, as shown by Visscher et al. ${ }^{39}$.

The chronic illnesses most strongly related to the risk of malnutrition were respiratory (chronic obstructive pulmonary disease, allergies, pulmonary hypertension), heart (ischemic heart disease, congestive heart failure) and kidney disease (kidney failure). The first two are more prevalent and the leading cause of death among the elderly in middle-income countries, such as Brazil ${ }^{40}$.

Schilp et al. ${ }^{7}$ evaluated the incidence of malnutrition in the elderly $(65-85$ years $)$ during a nine-year follow-up and found an association between two or more chronic diseases and the risk of malnutrition. Malnutrition has also been found to be related to hospital-acquired pneumonia $^{41}$ and increased length of hospitalization ${ }^{42}$.

Although the association of acute and chronic illnesses with risk of malnutrition is not yet fully understood, it has been documented by several studies in the literature. The relationship between these factors is likely related to the catabolic effects of infection, inflammation or trauma. The release of inflammatory mediators such as cytokines (interleukin - 1, interleukin -6 and alpha-tumor necrosis factor), glucocorticoids, and catecholamine may cause changes in metabolism, appetite, and in the absorption and assimilation of nutrients ${ }^{43}$, resulting in a vicious circle of illness and malnutrition.

The present study shows some points that might be worthy of attention. Firstly, the quality of the data collected, with the exclusion of the elderly who had hearing or severe vision impairments, minimizing the bias of cognition and communication, the bedridden and wheelchair-using elderly people who guaranteed the standardization and measurement of the anthropometric measures, as well as the participants who presented changes of the cognitive state. In order to assess a specific group as to nutritional impairment, it was decided not to include the elderly with cognitive decline. Cognitive decline causes sensorineural alterations that can trigger anorexia and, consequently, decrease food intake and increase the risk of malnutrition ${ }^{44}$. Thus, the early detection of elderly people at risk of malnutrition is extremely important because it aggravates the prognosis of their condition, even though there is no consensus on what determines nutritional deficit in this group ${ }^{45}$. MNA made it easier to compare the present findings to those obtained in different populations ${ }^{46}$.

On the other hand, the cross-sectional design of our study may have been a limitation, since it does not allow establishing the direction of associations identified. Additionally, although the sample was made up from individuals living in 24 different cities in south-eastern Brazil, covering an area of $33,594 \mathrm{~km}^{2}$ with mean human development index of $0.717^{16}$, 
our findings may not be entirely generalizable, since the interviews were performed only with individuals who were available on the scheduled dates. Considering that depression is directly related to risk of malnutrition in the elderly, it should also be analyzed in further studies. Finally, the information about health conditions was self-reported, thus misclassifications bias cannot be ruled out.

\section{CONCLUSION}

The present study found that the risk of malnutrition was more common among female elderly individuals who had no formal education, identified as black-skinned, with lower income levels, not living with a partner, smokees or with respiratory, heart or kidney diseases. We hope that the identification of biological and social characteristics associated with malnutrition will contribute to the understanding of this phenomenon in elderly populations and turn the spotlight on the need for preventive interventions. The treatment of established malnutrition is far more complex and costly, which may hinder the reversal of this condition in a population as vulnerable as the elderly.

\section{REFERENCES}

1. Kaiser MJ, Bauer JM, Rämsch C, Uter W, Guigoz Y, Cederholm T, et al. Frequency of malnutrition in older adults: a multinational perspective using the mini nutritional assessment. J Am Geriatr Soc 2010; 58(9): 1734-8. DOI: $10.1111 /$ j.1532-5415.2010.03016.x

2. Dent E, Visvanathan R, Piantadosi C, Chapman I. Nutritional screening tools as predictors of mortality, functional decline, and move to higher level care in older people: a systematic review. J Nutr Gerontol Geriatr 2012; 31(2): 97-145. DOI: 10.1080/21551197.2012.678214

3. Roh, L, Braun J, Chiolero A, Bopp M, Rohrmann S, Faeh D, Swiss National Cohort Study Group. Mortality risk associated with underweight: a census-linked cohort of 31,578 individuals with up to 32 years of follow-up. BMC Public Health 2014; 14: 371. DOI: 10.1186/1471-2458-14-371

4. Otero UB, Rozenfeld S, Gadelha AM, Carvalho MS Mortalidade por desnutrição em idosos, região Sudeste do Brasil, 1980-1997. Rev Saúde Pública 2002; 36(2): 141-8. DOI: 10.1590/S0034-89102002000200004

5. Sargento L, Satendra M, Almeida I, Sousa C, Gomes S, Salazar F, Lousada N, Palma RR. Nutritional status of geriatric outpatients with systolic heart failure and its prognostic value regarding death or hospitalization, biomarkers and quality of life. J Nutr Health Aging 2013; 17(4): 300-4. DOI: 10.1007/s12603-013-0030-y
6. Maia I, Xará S, Dias I, Parente B, Amaral TF. Nutritional screening of pulmonology department inpatients. Rev Port Pneumol 2014; 20(6): 293-8. DOI: 10.1016/j. rppneu.2014.01.004

7. Schilp J, Wijnhoven HA, Deeg DJ, Visser M. Early determinants for the development of undernutrition in an older general population: longitudinal aging study amsterdam. Br J Nutr 2011; 106(5): 708-17. DOI: 10.1017 / S0007114511000717

8. Aliabadi M, Kimiagar M, Ghayour-Mobarhan M, Shakei MT, Nematy M, Ilaty AA, et al. Prevalence of malnutrition in free living elderly people in Iran: a cross-sectional study. Asia Pac J Clin Nutr 2008; 17(2): 285-9.

9. Boulos C, Salameh P, Barberger-Gateau P. Factors associated with poor nutritional status among community dwelling Lebanese elderly subjects living in rural areas: results of the AMEL study. J Nutr Health Aging 2014; 18(5): 487-94. DOI: $10.1007 /$ s12603-013-0436-6

10. United Nations Population Fund (UNFPA) \& Help Age International. Ageing in the twenty-first century: a celebration and a challenge. 2012. [Internet]. Disponível em: http: / / www.unfpa.org/sites/default/ files / pub-pdf/ Ageing\%20report.pdf (Acessado em 06 de julho de 2015). 
11. Brasil. Instituto Brasileiro de Geografia e Estatística (IBGE). Censo Demográfico 2010. IBGE: 2010. [Internet]. Disponível em: http://www.censo2010. ibge.gov.br/sinopse/webservice/ (Acessado em 17 de junho de 2015).

12. Brasil. Instituto Brasileiro de Geografia e Estatística (IBGE). Síntese de Indicadores Sociais: uma análise das condições de vida da população brasileira. Rio de Janeiro: IBGE; 2014. 317 p.

13. Chatterji S, Byles J, Cutler D, Seeman T, Verdes E. Health, functioning and disability in older adults present status and future implications. Lancet 2015; 385(9967): 563-75. DOI: 10.1016/S0140-6736(14)61462-8

14. Ferreira LS, Amaral TF, Marucci MF, Nascimento LF, Lebrão ML, Duarte YA. Undernutrition as a major risk factor for death among older Brazilian adults in the community-dwelling setting: SABE survey. Nutrition 2011; 27(10): 1017-22. DOI: 10.1016/j.nut.2010.11.008

15. Folstein MF, Folstein SE, McHugh PR. "Mini-mental state". A practical method for grading the cognitive state of patients for the clinician. J Psychiatr Res 1975; 12(3): 189-98.

16. Bertolucci PH, Brucki SM, Campacci SR, Juliano Y. O Mini-Exame do Estado mental em uma população geral: impacto da escolaridade. Arq Neuro-Psiquiatr 1994; 52(1): 1-7. DOI: 10.1590/S0004-282X1994000100001

17. The Mini Nutritional Assessment (MNA). Nestlé nutrition/institute. [Internet]. Disponível em: http:/ / www.mna-elderly.com/forms/MNA_portuguese.pdf. (Acessado em 18 de julho de 2010).

18. Guigoz Y, Lauque, S, Vellas, BJ. Identifying the elderly at risk for malnutrition. The mini nutritional assessment. Clin Geriatr Med 2002; 18(4): 737-57.

19. Barone L, Milosavljevic M, Gazibarich B. Assessing the older person: is the MNA a more appropriate nutritional assessment tool than the SGA? J Nutr Health Aging 2003; 7(1): 13-7.

20. Lohman TG, Roche AF, Martorell R. Anthropometric standardization reference manual. Champaign: Human Kinetics Books; 1988.

21. Victora CG, Huttly, SR, Fuchs SC, Olinto MT. The role of conceptual frameworks in epidemiological analysis: a hierarchical approach. Int J Epidemiol 1997; 26(1): 224-7.

22. Lemeshow S, Hosmer DW. Applied logistic regression. Wiley Series in Probability and Statistics. New York: Wiley-Interscience Publication; 1989.

23. Boulos C, Salameh P, Barberger-Gateau P. The AMEL study, a cross sectional population-based survey on aging and malnutrition in 1200 elderly Lebanese living in rural settings: protocol and sample characteristic. BMC Public Health 2013; 13: 573. DOI: 10.1186/1471-2458-13-573
24. Brasil. Ministério da Saúde. Estatuto do Idoso. Brasília: Ministério da Saúde; 2009. 70 p.

25. Pryer JA, Rogers S. Epidemiology of undernutrition in adults in Dhaka slum households, Bangladesh. Eur J Clin Nutr 2006; 60(7): 815-22. DOI: 10.1038/sj.ejcn.1602385

26. Brasil. Governo de Minas Gerais. Panorama da economia mineira 2014. Secretaria de Estado de Desenvolvimento Econômico. [Internet]. Disponível em: http:/ / www.sede.mg.gov.br/images/documentos/ Estudos\%20transversais\%2030-12.pdf (Acessado em 07 de fevereiro de 2017).

27. Cuervo M, Ansorena D, Martinez-Gonzalez MA, Garcia A, Astiasarán I, Martinez JA. Impact of global and subjective mini nutritional assessment (MNA) questions on the evaluation of the nutritional status: the role of gender and age. Arch Gerontol Geriatr 2009; 49(1): 69-73. DOI: $10.1016 / j$. archger.2008.05.003

28. Mathers CD, Stevens GA, Boerma T, White RA, Tobias MI. Causes of international increases in older age life expectancy. Lancet 2015; 385(9967): 540-8. DOI: 10.1016/S0140-6736(14)60569-9

29. Rosa TE, Mondini L, Gubert MB, Sato GS, Benício $\mathrm{MH}$. Segurança alimentar em domicílios chefiados por idosos, Brasil. Rev Bras Geriatr Gerontol 2012; 15(1): 69-7. DOI. 10.1590/S1809-98232012000100008

30. Timpini A, Facchi E, Cossi S, Ghisla MK, Romanelli G, Marengoni A. Self-reported socio-economic status, social, physical and leisure activities and risk for malnutrition in late life: a cross-sectional populationbased study. J Nutr Health Aging 2011; 15(3): 233-8.

31. Moreira PA, Padrão PD. Educational and economic determinants of food intake in Portuguese adults: a cross-sectional survey. BMC Public Health 2004; 4: 58. DOI. 10.1186/1471-2458-4-58

32. Brasil. Instituto de Pesquisa Econômica Aplicada (IPEA). Retrato das desigualdades de gênero e raça. 2015. [Internet]. Disponível em: http://www.ipea. gov.br/retrato/ (Acessado em 21 de julho de 2015).

33. Oliveira BL, Thomaz EB, Silva RA. Associação da cor/ raça aos indicadores de saúde para idosos no Brasil: um estudo baseado na pesquisa nacional por amostra de domicílios (2008). Cad Saúde Pública 2014; 30(7): 1438-52. DOI: 10.1590/0102-311X00071413

34. Locher JL, Robinson CO, Roth DL, Ritchie CS, Burgio $\mathrm{KL}$. The effect of the presence of others on caloric intake in homebound older adults. J Gerontol A Biol Sci Med Sci 2005; 60(11): 1475-8.

35. Romero-Ortuno R. Casey AM, Cunningham CU, Squires S, Prendergast D, Kenny RA, et al. Psychosocial and functional correlates of nutrition among communitydwelling older adults in Ireland. J Nutr Health Aging 2011; 15(7): 527-31. 
36. Coqueiro RD, Barbosa AR, Borgatto AF. Nutritional status, health conditions and socio-demographic factors in the elderly of Havana, Cuba: data from SABE survey. J Nutr Health Aging 2010; 14(10): 803-8.

37. Fares D, Barbosa AR, Borgatto AF, Coqueiro RS, Fernandes MH. Fatores associados ao estado nutricional de idosos de duas regiões do Brasil. Rev Assoc Med Bras 2012; 58(4): 434-41. DOI: 10.1590/ S0104-42302012000400013

38. Audrain-McGovern J, Benowitz NL. Cigarette smoking, nicotine, and body weight. Clin Pharmacol Ther 2011; 90(1): 164-8. DOI: 10.1038/clpt.2011.105

39. Visscher TL, Seidell JC, Menotti A, Blackburn H, Nissinen A, Feskens EJ, et al. Underweight and overweight in relation to mortality among men aged 40-59 and 50-69 years: the seven countries study. Am J Epidemiol 2000; 151(7): 660-6. DOI: 10.1093/ oxfordjournals.aje.a010260

40. Prince MJ, Wu F, Guo Y, Robledo LM, O’Donnell M, Sullivan R, et al. The burden of disease in older people and implications for health policy and practice. Lancet 2015; 385(9967): 549-62. DOI: $10.1016 /$ S0140-6736(14)61347-7
41. Rothan-Tondeur M, Meaume S, Girard L, Weill-Engerer S, Lancien E, AbdelmalakS, et al. Risk factors for nosocomial pneumonia in a geriatric hospital: a control-case onecenter study. J Am Geriatr Soc 2003; 51(7): 997-1001.

42. PirlichM, Schutz T, Norman K, Gastell S, LübkeHJ, Bischoff SC, et al. The German hospital malnutrition study. Clin Nutr 2006; 25(4): 563-72. DOI: 10.1016/j.clnu.2006.03.005

43. Hickson M. Malnutrition and ageing. Postgrad Med J 2006; 82(963): 2-8. DOI: 10.1136/pgmj.2005.037564

44. Kvamme JM, Grønli O, Florholmen J, Jacobsen BK. Risk of malnutrition is associated with mental health symptoms in community living elderly men and women. the tromsø study. BMC Psychiatry 2011; 11: 112. DOI: $10.1186 / 1471-244 X-11-112$

45. Castro PR, Frank AA. Miniavaliação nutricional na determinação do estado de saúde de idosos com ou sem doença de Alzheimer: aspectos positivos e negativos. Estudo Interdiscipl Envelhec 2009; 14(1): 45-64.

46. Guigoz Y. The Mini Nutritional Assessment (MNA) review of the literature - What does it tell us? J Nutr Health Aging 2006; 10(6): 485-7.

Received on: 10/24/2016

Final version presented on: 07/06/2017

Accepted on: 02/22/2017 